\title{
Novel roles for Notch, Wnt and Hedgehog in hematopoesis derived from human pluripotent stem cells
}

\author{
CHANTAL CERDAN and MICKIE BHATIA* \\ McMaster Stem Cell and Cancer Research Institute (SCC-RI), McMaster University, \\ Hamilton, Ontario, Canada
}

\begin{abstract}
Human pluripotent stem cells (PSCs) derived from a number of different sources, including reprogrammed adult somatic cells, provide a powerful cellular system to study signaling pathways implicated in cell fate decisions, and generate new sources of cells for regenerative medicine. To realize this potential, it is essential to control the direction and efficiency of human PSC differentiation. Although Notch, Wnt and Hedgehog (HH) signaling pathways have been implicated in the self-renewal/proliferation of hematopoietic stem/progenitor cells, both in vitro and in vivo, their roles in differentiation processes remain poorly explored. This review describes the role(s) of these pathways in the adult and embryonic hematopoietic system of mice and humans, with a particular emphasis on our recent studies on the hematopoietic development of human embryonic stem cells (hESCs). Understanding the individual and collective contributions of Notch, Wnt and HH signaling to the initial development of hematopoiesis is critical for achieving successful ex vivo expansion and differentiation of hematopoietic stem cells (HSCs) from human PSCs that will retain bona fide function comparable to adult-derived HSCs.
\end{abstract}

KEY WORDS: human pluripotent stem cell, hematopoiesis, Wnt, Notch, Hedgehog

\section{Introduction}

Hematopoietic stem cells (HSCs) are responsible for life-long production of the blood system. To this end, HSCs must establish a balance between the two opposing cell fates of self-renewal - for maintenance of the HSC pool - and differentiation into terminally mature progenies (reviewed in Giebel and Bruns, 2008). In clinical therapy, HSCs are typically derived from adult tissues [bone marrow (BM), umbilical cord blood (UCB), or mobilized peripheral blood (MPB)] and have been successfully used to treat a variety of acquired/genetic disorders and malignancies. However, the limited availability of adult-derived HSCs and their compromised in vivo potential after ex vivo culture (Attar and Scadden, 2004) have hampered their use in large-scale clinical applications; therefore, calling for a more readily available and renewable source of transplantable cells. In this regard, human embryonic stem cells (hESCs) (Thomson et al., 1998; Reubinoff et al., 2000) and the more recently derived induced pluripotent stem cells (iPSCs) (Takahashi and Yamanaka, 2006; Park et al., 2008; Yu et al., 2007) provide two alternative sources of pluripotent stem cells (PSCs) that demonstrate both indefinite prolifera- tive capacity in vitro (Avery et al., 2006) and pluripotent differentiation potential (Yu and Thomson, 2008), including the potential to form blood.

HSCs are functionally defined by their ability to reconstitute the hematopoietic system of immunodeficient animals, e.g. NOD/ SCID mice (Dick et al., 1997; Mazurier et al., 2003) and equally contribute to functional reconstitution in human transplant settings (Grewal et al., 2003). While ectopic transcription factors of the $C d x / H o x$ pathway can modulate the functional behavior of adult HSCs (reviewed in Klump et al., 2005) and confer HSC properties to mouse ESCs (Kyba et al., 2002; Wang etal., 2005a), this is not the case with hESCs where the generation of "putative" HSCs, using various methodologies, animal recipients and injection routes has yielded significant lower levels of reconstitution, as shown by our laboratory (Wang et al., 2005b; Ji et al., 2008) and later others (Lu et al., 2007a; Lee et al., 2008; Narayan et al.,

\footnotetext{
Abbreviations used in this paper: EB, embryoid body; hESC, human embryonic stem cell; HH, hedgehog; HSC, hematopoietic stem cell; PSC, pluripotent stem cell.
}

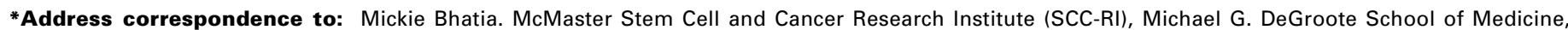
McMaster University, 1200 Main Street West, MDCL 5029, Hamilton, Ontario, Canada, L8N 3Z5.

e-mail: mbhatia@mcmaster.ca - web: www.fhs.mcmaster.ca/SCCRI
}

Final, author-corrected PDF published online: 15 March 2010.

ISSN: Online 1696-3547, Print 0214-6282

(c) 2010 UBC Press

Printed in Spain 
2006; Tian et al., 2006; Ledran et al., 2008).

In vitro, the hematopoietic potential of hESCs is routinely assessed by two methodologies that are largely adapted from the murine system: 1) coculture with stromal cells and 2) aggregation into three-dimensional structures known as embryoid bodies (EBs) (both reviewed in Tian and Kaufman, 2008). Both methodologies allow for the spontaneous differentiation of hESCs into blood lineages, albeit at low efficiency. This efficiency can be enhanced through manipulation of extracellular or intracellular regulators (Wang et al., 2005c; Menendez et al., 2005). However, the true contribution of extrinsic pathways that regulate this complex and dynamic process needs to be adequately defined for achieving controlled and efficient hematopoietic differentiation. By providing access to isolated cell populations at different developmental stages, human PSC cultures allow us to more precisely dissect the signaling and timing requirements for early hematopoiesis.

Based on the differentiation procedures outlined above, a series of studies (Chadwick et al., 2003; Cerdan et al., 2004; Chadwick et al., 2003; Wang et al., 2005d; Wang et al., 2004; Ji et al., 2008) from our laboratory have provided a detailed phenotypic and temporal roadmap of hESC-derived hematopoietic development towards myeloid/erythroid lineages. This work demonstrated that cells developing within EBs treated with hematopoietic cytokines (mainly SCF and FLT3L) and the ventral mesoderm inducer BMP-4 remain uncommitted to the hematopoietic cell fate up to 10 days of development, as defined by the lack of CD45 expression and colony forming unit (CFU) activity (Chadwick et al., 2003). During this developmental window, a subset of endothelial-like cells expressing PECAM-1, Flk-1/KDR and VEcadherin, but not CD45 (termed CD45 negPFV) develops, which following clonal isolation and differentiation in culture, gives rise to both endothelial and hematopoietic progenies (Wang et al., 2004); therefore, representing the equivalent of the "hemangioblast" or "hemogenic endothelial" precursor identified across species and hematopoietic sites (Huber et al., 2004; Choi etal., 1998; Nishikawa etal., 1998; Jaffredo etal., 2000; Zambidis et al., 2005; Kennedy et al., 2007; Lu et al., 2007b).

The hematopoietic system is believed to arise from common progenitor cells of mesodermal origin and to proceed through an initial "primitive/yolk sac" stage comprising mostly erythrocytes and macrophages, followed by "definitive" hematopoiesis encompassing the full range of blood cells encountered in the adult organism, including HSCs. Signaling from critical growth/morphogenetic factors that are shared between vertebrates influences both primitive and definitive hematopoiesis. Contrary to hematopoietic cytokines such as FLT3L, SCF and TPO that can promote HSC survival but not expansion (Murdoch et al., 2002), bone morphogenetic proteins (BMP) (Sadlon et al., 2004), Notch (Radtke et al., 2005), Wnt (Wodarz and Nusse, 1998) and Hedgehog $(\mathrm{HH})$ (Baron, 2001) have been established as key stem cell signaling pathways involved in fate specification, self-renewal, and differentiation. With the exception of BMP signaling similarly required for hematopoietic differentiation of mouse and human ESCs (reviewed in McKinney-Freeman and Daley, 2007), none of the Notch, Wnt and $\mathrm{HH}$ pathways have been explored with respect to their ability to regulate early human hematopoiesis.

Accordingly, this review summarizes our current knowledge about the roles of Notch, Wnt and $\mathrm{HH}$ pathways in the regulation of adult and embryonic hematopoiesis with a particular emphasis on recent progress of our laboratory on the hematopoietic development of hESCs in the context of these pathways and comparison with the mouse system.

\section{The Notch pathway}

The Notch signaling pathway regulates a broad spectrum of stem cell fate decisions such as neurogenesis, myogenesis and hematopoiesis (Chiba, 2006). Notch signaling is activated through four receptors (Notch1-4) that can interact in a redundant manner with five ligands of the Delta/Jagged family (Bray, 2006). Ligand binding triggers a $\gamma$-secretase-dependent proteolytic cleavage of Notch receptor and the release of Notch intracellular domain (NICD) to the nucleus (De Strooper et al., 1999), which in turn displaces the co-receptors associated with CSL transcription factors (CBF1 in humans; RBPJ in mice). Activating transcription factors are then recruited and expression of target genes such as Hairy and Enhancer of Split HES1, HES5 and Deltex1 is induced (Bray, 2006; Davis and Turner, 2001).

Although recently extended to the regulation of megakaryopoiesis (Mercher etal., 2008), the role of Notch signaling has been best characterized in T cell lineage specification (reviewed in Radtke et al., 2004) and its deregulation found associated with leukemia (mainly T-ALL) in humans (Grabher et al., 2006). In adult hematopoiesis, activation of Notch signaling has been reported to promote HSC expansion/self-renewal in both mice and humans (Karanu et al., 2000; Karanu et al., 2001; Karanu et al., 2003; Varnum-Finney et al., 1998; Ohishi et al., 2002; Carlesso et al., 1999; Dando et al., 2005); however, lossof-function studies in mice have not clearly supported this conclusion (Radtke et al., 1999; Saito et al., 2003; Mancini et al., 2005; Maillard et al., 2008). In particular, inactivation of Notch receptors (Notch1, Notch2), ligands (Jagged-1) or downstream effectors (CSL/RBPJ, Mastermind-like1) does not impair HSC function. In mouse embryonic hematopoiesis, gene ablation strategies have revealed non overlapping roles for Notch1 and Notch2 in definitive hematopoiesis and $\mathrm{B}$ cell development, respectively (Hadland et al., 2004; Robert-Moreno et al., 2008; Huppert et al., 2000; Krebs et al., 2004; Kumano et al., 2003; Xue et al., 1999). However, while Notch seems essential for the establishment of definitive HSCs in the embryo, it inhibits the generation of mesodermal and subsequent hematopoietic and endothelial lineages from mouse ESCs (Schroeder et al., 2006), leaving the role(s) of Notch signaling unclear during the earliest stages of hematopoietic development.

Corroborating the lack of convincing evidence that Notch pathway is involved in the maintenance of undifferentiated mouse ESCs (Nemir et al., 2006), several laboratories (Noggle et al., 2006; Fox etal., 2008; Yu et al., 2008), including ours (Lee, 2008), have confirmed the lack or minimal contribution of Notch signaling to the undifferentiated state of hESCs. Activation of Notch signaling by exogenous Jagged-1 promoted hESC hematopoiesis at greater levels than induced by any previously cytokine- or morphogen-mediated stimulation, thereby providing ready access to larger numbers of hematopoietic cells. Interestingly, knockdown of HES1 within the CD45 ${ }^{\text {negPFV }}$ subset resulted in reduced hematopoietic but enhanced endothelial output, suggesting that the commitment of bipotent precursors can be controlled by 
regulation of HES1 (Lee, 2008)). This preliminary finding suggests that Notch signaling may function in an analogous manner to the "lateral inhibition" model of cellular control first observed in Drosophila (reviewed in Radtke et al., 2005). This role of Notch may be of great value for directing human PSC specification into hematopoietic or endothelial fate exclusively. In this regard, our observation of a similar Notch-dependent regulation of hematopoietic development of human iPSCs indicates that the two cell types are similar with respect to their ability to respond to Notch signals. Since the biological effects of Notch activation are highly context-dependent, it is crucial to ascertain whether Notch-dependent promotion of hematopoiesis in human PSCs relies upon the presence of BMP-4 used in our differentiation system, which will likely provide a significant control over the biological functions of Notch and BMP within the endothelial/hematopoietic compartments. Although the role of Notch in the generation of bona fide HSCs from human PSCs remains to be assessed, our findings (Lee, 2008)) may have important implications as they suggest the possibility that activation of the Notch pathway may aid in stimulating the production of hematopoietic stem/progenitor or endothelial cells for both experimental and clinical applications.

\section{The Hedgehog pathway}

Conserved from Drosophila to humans, the Hedgehog $(\mathrm{HH})$ pathway has a central role in embryonic development and adult tissue homeostasis by controlling cell fate specification and pattern formation (reviewed in McMahon et al., 2003). The functional importance of this pathway is illustrated by the multiple birth defects and malignancies (notably leukemia) (Bai et al., 2008) associated with mutations and/or aberrant activation of the pathway (Villavicencio et al., 2000). Three HH ligands Sonic (SHH), Indian $(\mathrm{IHH})$ and Desert $(\mathrm{DHH})$ have been identified in mammals that can bind interchangeably to two related twelve-pass membrane Patched (Ptc) receptors (reviewed in Ingham and McMahon, 2001). In the absence of ligand, Ptc antagonizes the pathway by preventing the activity of another transmembrane protein Smoothened (Smo) (Lum and Beachy, 2004; Alcedo and Noll, 1997; Taipale et al., 2002). Binding of $\mathrm{HH}$ ligands to Ptc relieves this inhibition, which activates target gene transcription through the regulation of Glioblastoma (Gli) family of transcription factors (Gli1, Gli-2, Gli-3) (reviewed in Koebernick and Pieler, 2002; AzaBlanc and Kornberg, 1999). The different Gli proteins exhibit activating or repressing transcriptional activities depending on proteolytic processing of the full-length proteins. Gli-1 and Gli-2 mainly act as transcriptional activators, while Gli-3 generates a repressor form (Gli3R) in the absence or inhibition of $\mathrm{HH}$ signaling (Dai etal., 1999; Wang et al., 2000; Ingham and McMahon, 2001). Although functional significance of Gli-3 has been demonstrated by genetic inactivation (Litingtung et al., 2002), the molecular mechanisms that control Gli-3 interactions and targets are largely undefined, whereas the dynamic interplay between Gli-1 and Gli2 signaling is well documented. Activation and repression of $\mathrm{HH}$ pathway, through interference with Smo activity, can be achieved with synthetic agonists (purmorphamine) (Sinha and Chen, 2006) and antagonists (cyclopamine) (Taipale et al., 2000), respectively.

Studies using mouse embryos and ESCs have implicated the $\mathrm{HH}$ pathway $(\mathrm{IHH})$ in early hemato-vascular development (Dyer et al., 2001; Byrd etal., 2002; Baron, 2003). However, in vivogenetic studies have been of limited utility in dissecting the role of the pathway due to either embryonic lethality induced by the targeted components (Chiang et al., 1996) or the implication of other pathways (for example, Wnt or BMP).

In humans, our laboratory has been the first to reveal a role for $\mathrm{HH}$ pathway $(\mathrm{SHH})$ in the regulation of adult HSCs (Bhardwaj et al., 2001). Upon investigation of the role of this pathway in hESCderived hematopoiesis, we found that hESCs activated by exogenous $\mathrm{SHH}$ or purmorphamine responded by a reduction in the size of the committed hematopoietic but not the hemogenic endothelial cell compartment. Conversely, antagonism of $\mathrm{HH}$ signaling with cyclopamine or siRNA against Smo increased blood development and was associated with the processing of Gli-3 into its repressor form (Ramos-Mejia, 2008). This effect was found to be BMP-4-dependent, in agreement with the established connection between $\mathrm{HH}$ and BMP pathways in adult HSC biology (reviewed in Baron, 2003). More importantly, cyclopamine favored the development of definitive erythropoiesis from hESCs as judged by adult $\beta$ globin expression, providing circumstantial evidence of the potential to generate definitive hematopoietic lineages. Although the role of $\mathrm{HH}$ signaling in $\mathrm{hESC}$ s may seem contradictory to prior evidence in other species where $\mathrm{HH}$ has been established as a positive regulator of primitive or definitive hematopoiesis (Maye et al., 2000; Dyer et al., 2001; Byrd et al., 2002; Gering and Patient, 2005), it is consistent with our previous report implicating activation of $\mathrm{HH}$ signaling in the exhaustion of mouse adult HSCs (Trowbridge et al., 2006a).

Taken together, our findings indicate that inhibition of $\mathrm{HH}$ signaling in hESCs may be important for inducing definitive hematopoiesis, thereby raising the possibility to generate bona fide HSCs from hESCs. Assessing this possibility in vivo is key as it has been hypothesized that the compromised reconstituting capacity of HSCs derived from ESCs may be accounted for by their resemblance with cells derived from the yolk sac (reviewed in Palis and Yoder, 2001).

\section{The Wnt pathway}

The evolutionary conserved Wnt pathway diversifies into two main branches, e.g. canonical ( $\beta$-catenin-dependent) and noncanonical ( $\beta$-catenin-independent) that play critical roles in specifying cellular fates and movements, respectively, during both embryonic development and adult tissue regeneration (reviewed in Logan and Nusse, 2004; Reya and Clevers, 2005; Uusitalo et al., 1999). Wnt ligands signal through binding to seven transmembrane Frizzled (Fzd) receptors and single transmembrane lipoprotein receptor-related protein (LRP) 5 or 6 co-receptors (Wu and Nusse, 2002). Canonical signaling mediated by ligands such as Wnt3a inhibits a multiprotein degradation complex consisting minimally of axin, adenomatous polyposis coli (APC) and glycogen synthase kinase 3 beta (GSK3 $\beta$ ). This inhibition culminates in nuclear translocation of $\beta$-catenin, enabling it to interact with $\mathrm{T}$ cell factor (TCF)/lymphoid enhancer factor (LEF) transciption factors to regulate gene expression (Khon and Moon, 2005). Noncanonical signaling, which is much less defined, is mediated by ligands such as Wnt11 that use the same Fzd receptors but ROR2/RYK as co-receptors (Nusse, 2008; Lu et al., 2004). This pathway stimulates the Jun $\mathrm{NH}$-terminal kinase (JNK), $\mathrm{Ca}^{2+}$ / 
CaMKII and PKC pathways (reviewed in Kohn and Moon, 2005). Both pathways interact with each other, and in some cases, noncanonical signaling antagonizes the canonical pathway (Kuhl, 2002).

Even though the role of canonical signaling on the regulation of adult hematopoiesis has been studied in great detail, controversy remains, possibly explained by differences in strength and duration of Wnt signaling or redundancy with other pathways (Reya et al., 2003; Willert et al., 2003; Trowbridge et al., 2006b; Kirstetter et al., 2006; Scheller et al., 2006; Qian et al., 2008; Koch et al., 2008). In the context of development, genetic studies have demonstrated the requirement for canonical signaling in the formation of mesoderm (Liu et al., 1999; Lako et al., 2001; Kelly et al., 2004; Huelsken et al., 2000; Gadue et al., 2006). However, studies using mouse ESCs have failed to assign specific roles for this pathway during commitment of mesoderm to the hematopoietic lineage (Naito et al., 2006; Wang et al., 2007; Nostro et al., 2008), thus precluding tangible extrapolations from mouse to human. The role of non-canonical signaling on human hematopoiesis has been far less characterized as only one study by our laboratory has implicated the pathway in the regulation of adult HSCs in vivo (Murdoch et al., 2003).

In hESCs, the role of Wnt pathways was thought to be irrelevant to hematopoiesis until the demonstration that canonical but not non-canonical signaling could support bipotent hemogenic cell development (Woll et al., 2008). Since this study, recent advances from our laboratory have provided insights into the uniqueness of the biological functions of the two pathways. We found that non-canonical (Wnt11) and canonical (Wnt3A) Wnts affected different target populations and stages of hematopoietic development (Vijayaragavan et al., 2009). Consistent with its previously defined role in human adult cells (Van Den Berg et al., 1998) and mouse ESCs (Lako et al., 2001; Lengerke et al., 2008), canonical signaling increased proliferation of blood committed progenitors when administered during the proper window of time during EB development (Vijayaragavan et al., 2009). However, we did not observe any positive influence of canonical Wnt signaling on mesoderm specification of hESCs as the work with mouse ESCs indicates (Lako et al., 2001; Wang et al., 2007). A short pulse of non-canonical signaling was necessary and sufficient to control exit of hESCs from the pluripotent state and subsequent entry into the mesendoderm/mesoderm lineages as mapped by the expression of representative markers and the induction of a unique cell population co-expressing Brachyury, Fzd7 and E-cadherin (Brachyury $/ / F_{2 d 7} / /$ E-cadherin ${ }^{+}$). SiRNAmediated knockdown of Fzd7 decreased the size of Brachyury ${ }^{+} /$ Fzd7+/E-cadherin ${ }^{+}$population and subsequent hematopoietic compartments (Vijayaragavan et al., 2009). In addition, the generation of this population was dependent upon EB formation and lost in monolayer cultures of hESCs, illustrating the importance of three-dimensional structures that more closely mimic gastrulation organization.

Taken together, our findings (Vijayaragavan et al., 2009) provide the first evidence of a unique role for non-canonical signaling in early specification of hematopoiesis from hESCs, whereas canonical signaling affects the proliferation of cells already fated to blood. These studies provide a valuable model system for examining the possibility of chronological activation and interaction between non-canonical and canonical signaling in the cellular progression from mesoderm to blood. Furthermore, the non-canonical induced Brachyury ${ }^{+} / \mathrm{Fzd}^{+} / \mathrm{E}^{-}$-cadherin ${ }^{+}$population also provides the opportunity for addressing the relationship between this subset and the putative "mesendodermal" precursor described in zebrafish and Xenopus (Kimelman and Griffin, 2000; Rodaway and Patient, 2001), for which evidence is lacking in humans. As recently outlined in mouse ESCs (Lengerke et al., 2008), the specific functions of both Wnt pathways will have to be revisited in the context of their cross talk with known hematopoietic regulators such as BMP and $C d x / H o x$. The controversial function of canonical signaling on the reconstituting capacity of adult HSCs (Reya et al., 2003; Kirstetter et al., 2006; Scheller et al., 2006; Koch et al., 2008), combined with our present findings in hESCs, underscores the importance of fine tuning the strength and duration of Wnt signaling towards therapeutically exploiting the balance between self-renewal and lineage commitment of HSCs.

\section{Towards an integrated view of $\mathrm{HH}$, Wnt and Notch signaling in hematopoiesis}

Multiple studies have suggested that Notch, Wnt and $\mathrm{HH}$ pathways can network together and with other signaling pathways to establish or regulate biological processes during embryogenesis and throughout adulthood (Hing etal., 1994; Maloof etal., 1999; Hooper, 1994). Despite the established connection between BMP and Notch, Wnt and HH pathways (Dahlqvist et al., 2003; Itoh et al., 2004; Nobta et al., 2005; Takizawa et al., 2003; Sumi et al., 2008; Lengerke et al., 2008; Baron, 2003), it remains unclear whether these pathways operate in direct network with one another in the context of the hematopoietic system. However, the importance of concerted regulation of hematopoiesis by distinct signaling pathways has been largely illustrated in the mouse (Pearson et al., 2008). For example, interplay between Notch and cytokine-activated pathways such as FGF, PDGF, TGF $\beta$, VEGF, G-CSF or GM-CSF has been found to modulate expression of Notch components (Bigas et al., 1998; Reya et al., 2003). Notch and Wnt signaling synergize to maintain the HSC/ multipotent progenitor pool, which is likely accomplished through the regulation of expression of Notch target genes, and Notchdependent inhibition of HSC differentiation by Wnt signaling (Duncan et al., 2005; Trowbridge et al., 2006b). Canonical Wnt and Notch signaling, which independently promote primitive erythropoiesis and cardiogenesis in mouse ESCs, respectively, set connections through reciprocal regulation of Notch (Numb) and Wnt (Sfrp1, Sfrp5, Dkk1, Wnt5a) pathway inhibitors to drive cellular differentiation specifically towards erythropoiesis (Cheng et al., 2008). In addition to cooperating with Notch, Wnt signaling has been shown to work in concert with other pathways at different stages of mouse or human hematopoiesis. For instance, the induction of mesendodermal precursors seems to require cooperative interactions between canonical Wnt and TGF $\beta$ signaling in both mouse and human ESCs (Gadue et al., 2006; Sumi et al., 2008; Nostro et al., 2008), although the balance between these pathways plays crucial roles in the ultimate decision of lineage specification. In addition, the connection of $\mathrm{HH}$ pathway with Notch and Wnt, as well as with proliferative/anti-apoptotic signaling pathways (FGF, IGF) regulates hematopoiesis. However, these connections have been best described in malignant he- 
matopoiesis (Sengupta etal., 2007) and poorly explored in normal development.

In addition to signaling cues, intrinsic determinants known to be involved in hematopoiesis engage with Notch and $\mathrm{HH}$ signaling. Of interest, hematopoietic transcription factors (SCL/TAL-1, RUNX1, HOXB4) (Orkin and Zon, 2002; Hochman et al., 2006) and chromatin regulators (Palaparti et al., 1997) suggest the participation of these pathways in the regulation of complex regulatory networks. Undoubtedly, further research is required to elucidate the integration of major extrinsic pathways into transcriptional and epigenetic regulatory networks. As recently explored during the undifferentiated state of mouse ESCs with respect to LIF and BMP pathways (Chen et al., 2008), elucidation of the integration of $\mathrm{HH}$, Notch and Wnt signals with core genetic and epigenetic networks during hematopoietic development of human PSCs should provide a strong foundation for more controlled manipulation of these pathways.

\section{Concluding remarks}

Capitalizing on insights gained from studies using vertebrate embryos, mouse ESCs, and most importantly adult-derived human HSCs, our findings have begun to unravel novel and distinct roles for Notch, Wnt and HH pathways in the regulation of hESCderived hematopoiesis (see Fig. 1). Further work is needed to ascertain whether the increased "quantity" of hematopoietic cells derived from hESCs that we observed in response to the manipulation of Notch, Wnt and $\mathrm{HH}$ pathways can amount to a better "quality" of cells that possess bona fide HSC function.

These studies illustrate the value of (i) cell culture systems
(EBs) and soluble growth/morphogenetic factors as a means to regulate the sequence of events and cell populations developing from the exit of pluripotent state to blood commitment and differentiation, (ii) Notch, Wnt and $\mathrm{HH}$ as important candidate pathways for regulating distinct and critical aspects of this development, (iii) temporal and stage specific manipulation of these pathways. This latter notion, which speaks to the invaluable contribution of concepts learned from developmental biology, is only beginning to be exploited in the hESC field. Although it is tempting to speculate that hESCs will behave more like mESCs as both systems share critical transcriptional pathways and pose a challenge for the generation of bona fide HSCs, our work underscores the existence of differences between the species through their disparate responsiveness to $\mathrm{HH}$ pathway or single-gene (HOXB4) reconstitution strategies. In light of these observations, it seems important to examine the situation in other model systems such as non-human primates, as divergent views remain on the origin of human definitive hematopoiesis between the epiblast-derived splanchnopleural mesoderm (Tavian et al., 2001) and hypoblast (Bianchi et al., 1993).

While the individual contributions of Notch, Wnt and HH pathways to the hematopoietic development of hESCs are only beginning to be investigated as outlined by our studies, the impact of their collective contribution should help determine whether combinatorial manipulation of these pathways may prove more powerful than single manipulation strategies towards influencing the development of hematopoietic lineages. However, the mechanistic complexity by which these pathways transmit intercellular and/or intracellular signals complicates the situation and raises a critical issue of selectivity. This is exemplified by (i) the growing
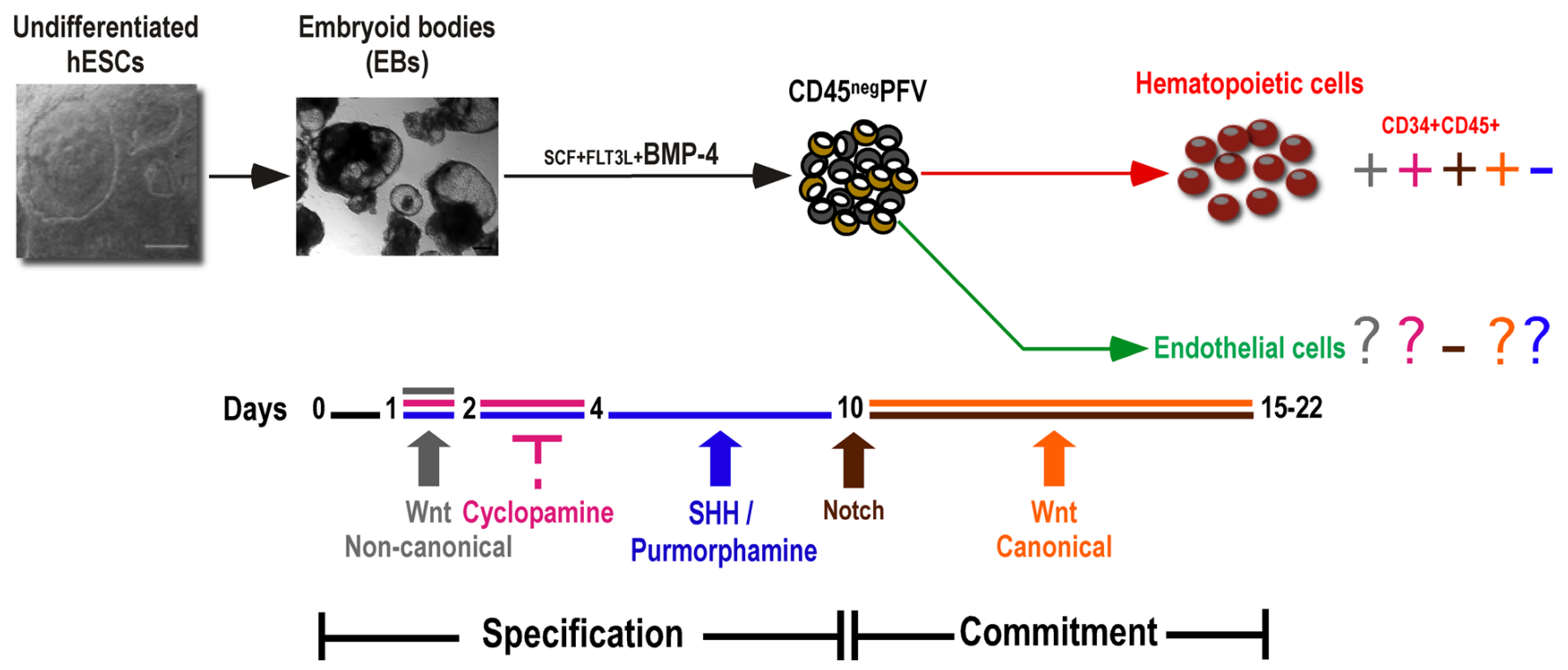

Fig. 1. Cellular and temporal roadmap of hematopoietic development of human embryonic stem cells (hESCs). Undifferentiated hESC colonies were differentiated into embryoid bodies (EBS) in differentiation medium supplemented with SCF, FLT3L and BMP-4 for the duration (days 1 - 1522) of EB development. Based on our previous studies (Wang et al., 2004), this developmental scheme can be divided in two phases. Days 0-10

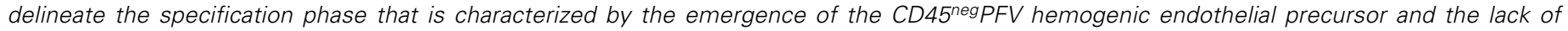
committed hematopoietic (CD34+CD45+) and endothelial cells. These latter populations emerge during the commitment phase from day 10 onwards. Different colors refer to activation of the different pathways as well as inhibition of the hedgehog (HH) pathway (cyclopamine). + and - signs indicate enhanced and decreased hematopoietic (or endothelial) output, respectively, as determined at days 15-22 of EB differentiation in response to manipulation of each pathway for the indicated time window. Question marks refer to unknown data. 
number of negative or positive regulatory loops within these pathways, (ii) the interrelationships with hematopoietic "niches", and (iii) the promiscuous receptor/ligand interactions, along with post-translational modifications of functional significance. In addition, the heterogeneous nature of ESC cultures, as demonstrated for human (Stewart et al., 2006; Bendall et al., 2007) and mouse (Hayashi et al., 2008) ESC self-renewal, will need to be accounted for as the functional consequences of such heterogeneity extend to our ability to understand and control lineage specification of human PSCs. Notwithstanding the complexity of PSC cultures and Notch, Wnt and $\mathrm{HH}$ signaling, these issues are essential to better address in the context of hematopoietic development towards achieving signal specificity and unlocking the potential of these pathways.

Stem cell manipulation strategies using synthetic regulators may be of great value for specifically targeting the activation or inhibition of these pathways. However, this raises concerns towards therapeutic applications given the implication of these pathways in hematopoietic malignancies (Grabher et al., 2006; Sengupta et al., 2007; Aster et al., 2008; Deshpande and Buske, 2007; Petropoulos et al., 2008), and the exhaustion of HSC potential upon sustained activation (Trowbridge et al., 2006b). Although the use of synthetic regulators of $\mathrm{HH}$ signaling has been encouraging in many systems (Stecca and Ruiz i Altaba, 2002), this will be more challenging for Wnt due to the intricate interplay of both pathways and the involvement of GSK3 in multiple pathways such as $\mathrm{HH}$ (Jia et al., 2002). While our more advanced knowledge of the hESC biology sets the stage for characterizing the cell populations and developmental stages targeted by Notch, Wnt and $\mathrm{HH}$ signaling, the iPSC technology offers the attractive possibility of initiating a stepwise "dedifferentiation" of mature blood cells from somatic sources to multipotent HSCs without first passing through a pluripotent cell state. If true, manipulation of specific sets of extrinsic and intrinsic hematopoietic regulators may be facilitated by a more permissive epigenetic state of adult blood cells compared to PSCs, which may lead to in vitrogeneration of blood cells representing the multiples branches of the hematopoietic hierarchy. Moreover, the experimental model system of iPSCs provides a more relevant testing platform for in vitro models of hematological abnormalities, which is likely to contribute to a better understanding of how deregulation of these pathways could result in malignant hematopoiesis.

\section{References}

ALCEDO, J. and NOLL, M. (1997) Hedgehog and its patched-smoothened receptor complex: a novel signalling mechanism at the cell surface. Bio/ Chem378: 583 590.

ASTER, J.C., PEAR, W.S. and BLACKLOW, S.C. (2008) Notch signaling in leukemia. Annu Rev Patho/3: 587-613.

ATTAR, E.C. and SCADDEN, D.T. (2004) Regulation of hematopoietic stem cell growth. Leukemia 18: 1760-1768.

AVERY, S., INNISS, K. and MOORE, H. (2006) The regulation of self-renewal in human embryonic stem cells. Stem Cells Dev 15: 729-740.

AZA-BLANC, P. and KORNBERG, T.B. (1999) Ci: a complex transducer of the hedgehog signal. Trends Genet 15: 458-462.

BAI, L.Y., CHIU, C.F., LIN, C.W., HSU, N.Y., LIN, C.L., LO, W.J. and KAO, M.C. (2008) Differential expression of Sonic hedgehog and Gli1 in hematological malignancies. Leukemia 22: 226-228.

BARON, M.H. (2001) Molecular regulation of embryonic hematopoiesis and vascu- lar development: a novel pathway. J Hematother Stem Cell Res 10: 587-594.

BARON, M.H. (2003) Embryonic origins of mammalian hematopoiesis. Exp Hematol 31: 1160-1169.

BENDALL, S.C., STEWART, M.H., MENENDEZ, P., GEORGE, D., VIJAYARAGAVAN, K., WERBOWETSKI-OGILVIE, T., RAMOS-MEJIA, V., ROULEAU, A., YANG, J., BOSSE, M., LAJOIE, G. and BHATIA, M. (2007) IGF and FGF cooperatively establish the regulatory stem cell niche of pluripotent human cells in vitro. Nature 448: 1015-1021.

BHARDWAJ, G., MURDOCH, B., WU, D., BAKER, D.P., WILLIAMS, K.P., CHADWICK, K., LING, L.E., KARANU, F.N. and BHATIA, M. (2001) Sonic hedgehog induces the proliferation of primitive human hematopoietic cells via BMP regulation. Nat Immuno/2: 172-180.

BIANCHI, D.W., WILKINS-HAUG, L.E., ENDERS, A.C. and HAY, E.D. 1993. Origin of extraembryonic mesoderm in experimental animals: relevance to chorionic mosaicism in humans. Am J Med Genet 46: 542-550.

BIGAS, A., MARTIN, D.I. and MILNER, L.A. (1998) Notch1 and Notch2 inhibit myeloid differentiation in response to different cytokines. Mo/Ce// Bio/18: 2324 2333.

BRAY, S.J. (2006) Notch signalling: a simple pathway becomes complex. Nat Rev Mol Cell Biol7: 678-689.

BYRD, N., BECKER, S., MAYE, P., NARASIMHAIAH, R., ST-JACQUES, B., ZHANG, X., MCMAHON, J., MCMAHON, A. and GRABEL, L. (2002) Hedgehog is required for murine yolk sac angiogenesis. Development 129: 361-372.

CARLESSO, N., ASTER, J.C., SKLAR, J. and SCADDEN, D.T. (1999) Notch1induced delay of human hematopoietic progenitor cell differentiation is associated with altered cell cycle kinetics. Blood93: 838-848.

CERDAN, C., ROULEAU, A. and BHATIA, M. (2004) VEGF-A165 augments erythropoietic development from human embryonic stem cells. Blood 103: 2504-2512.

CHADWICK, K., WANG, L., LI, L., MENENDEZ, P., MURDOCH, B., ROULEAU, A and BHATIA, M. (2003) Cytokines and BMP-4 promote hematopoietic differentiation of human embryonic stem cells. Blood102: 906-915.

CHEN, X., XU, H., YUAN, P., FANG, F., HUSS, M., VEGA, V.B., WONG, E., ORLOV, Y.L., ZHANG, W., JIANG, J., LOH, Y.H., YEO, H.C., YEO, Z.X., NARANG, V., GOVINDARAJAN, K.R., LEONG, B., SHAHAB, A., RUAN, Y., BOURQUE, G., SUNG, W.K., CLARKE, N.D., WEI, C.L. and NG, H.H. (2008) Integration of external signaling pathways with the core transcriptional network in embryonic stem cells. Cel/133: 1106-1117.

CHENG, X., HUBER, T.L., CHEN, V.C., GADUE, P. and KELLER, G.M. (2008) Numb mediates the interaction between Wnt and Notch to modulate primitive erythropoietic specification from the hemangioblast. Development 135: 3447 3458.

CHIANG, C., LITINGTUNG, Y., LEE, E., YOUNG, K.E., CORDEN, J.L., WESTPHAL, H. and BEACHY, P.A. (1996) Cyclopia and defective axial patterning in mice lacking Sonic hedgehog gene function. Nature 383: 407-413.

CHIBA, S. (2006) Notch signaling in stem cell systems. Stem Cel/s 24: 2437-2447.

CHOI, K., KENNEDY, M., KAZAROV, A., PAPADIMITRIOU, J.C. and KELLER, G. (1998) A common precursor for hematopoietic and endothelial cells. Develop ment 125: 725-732.

DAHLQVIST, C., BLOKZIJL, A., CHAPMAN, G., FALK, A., DANNAEUS, K., IBANEZ, C.F. and LENDAHL, U. (2003) Functional Notch signaling is required for BMP4-induced inhibition of myogenic differentiation. Development 130: 6089-6099.

DAI, P., AKIMARU, H., TANAKA, Y., MAEKAWA, T., NAKAFUKU, M. and ISHII, S (1999) Sonic Hedgehog-induced activation of the Gli1 promoter is mediated by GLI3. J Biol Chem 274: 8143-8152.

DANDO, J.S., TAVIAN, M., CATELAIN, C., POIRAULT, S., BENNACEURGRISCELLI, A., SAINTENY, F., VAINCHENKER, W., PEAULT, B. and LAURET, E. (2005) Notch/Delta4 interaction in human embryonic liver CD34+ CD38cells: positive influence on BFU-E production and LTC-IC potential maintenance. Stem Cells 23: 550-560.

DAVIS, R.L. and TURNER, D.L. (2001) Vertebrate hairy and Enhancer of split related proteins: transcriptional repressors regulating cellular differentiation and embryonic patterning. Oncogene 20: 8342-8357.

DE STROOPER, B., ANNAERT, W., CUPERS, P., SAFTIG, P., CRAESSAERTS, K., MUMM, J.S., SCHROETER, E.H., SCHRIJVERS, V., WOLFE, M.S., RAY, 
W.J., GOATE, A. and KOPAN, R. (1999) A presenilin-1-dependent gammasecretase-like protease mediates release of Notch intracellular domain. Nature 398: 518-522.

DESHPANDE, A.J. and BUSKE, C. (2007) Knocking the Wnt out of the sails of leukemia stem cell development. Cell Stem Cel/1: 597-598.

DICK, J.E., BHATIA, M., GAN, O., KAPP, U. and WANG, J.C. (1997) Assay of human stem cells by repopulation of NOD/SCID mice. Stem Cel/s 15 Suppl 1: 199-203; discussion 204-197.

DUNCAN, A.W., RATTIS, F.M., DIMASCIO, L.N., CONGDON, K.L., PAZIANOS, G., ZHAO, C., YOON, K., COOK, J.M., WILLERT, K., GAIANO, N. and REYA T. (2005) Integration of Notch and Wnt signaling in hematopoietic stem cell maintenance. Nat Immuno/6: 314-322.

DYER, M.A., FARRINGTON, S.M., MOHN, D., MUNDAY, J.R. and BARON, M.H. (2001) Indian hedgehog activates hematopoiesis and vasculogenesis and can respecify prospective neurectodermal cell fate in the mouse embryo. Development 128: 1717-1730.

FOX, V., GOKHALE, P.J., WALSH, J.R., MATIN, M., JONES, M. and ANDREWS, P.W. (2008) Cell-cell signaling through NOTCH regulates human embryonic stem cell proliferation. Stem Cells 26: 715-723.

GADUE, P., HUBER, T.L., PADDISON, P.J. and KELLER, G.M. (2006) Wnt and TGF-beta signaling are required for the induction of an in vitromodel of primitive streak formation using embryonic stem cells. Proc Natl Acad Sci USA 103: 16806-16811.

GERING, M. and PATIENT, R. (2005) Hedgehog signaling is required for adult blood stem cell formation in zebrafish embryos. Dev Cel/8: 389-400.

GIEBEL, B. and BRUNS, I. (2008) Self-renewal versus differentiation in hematopoietic stem and progenitor cells: a focus on asymmetric cell divisions. Curr Stem Cell Res Ther 3: 9-16.

GRABHER, C., VON BOEHMER, H. and LOOK, A.T. (2006) Notch 1 activation in the molecular pathogenesis of T-cell acute lymphoblastic leukaemia. Nat Rev Cancer 6: 347-359.

GREWAL, S.S., BARKER, J.N., DAVIES, S.M. and WAGNER, J.E. (2003) Unrelated donor hematopoietic cell transplantation: marrow or umbilical cord blood? Blood 101: 4233-4244.

HADLAND, B.K., HUPPERT, S.S., KANUNGO, J., XUE, Y., JIANG, R., GRIDLEY, T., CONLON, R.A., CHENG, A.M., KOPAN, R. and LONGMORE, G.D. (2004) $A$ requirement for Notch1 distinguishes 2 phases of definitive hematopoiesis during development. Blood 104: 3097-3105.

HAYASHI, K., LOPES, S.M., TANG, F. and SURANI, M.A. (2008) Dynamic equilibrium and heterogeneity of mouse pluripotent stem cells with distinct functional and epigenetic states. Cell Stem Cel/3: 391-401.

HING, H.K., SUN, X. and ARTAVANIS-TSAKONAS, S. (1994) Modulation of wingless signaling by Notch in Drosophila. Mech Dev 47: 261-268.

HOCHMAN, E., KINSTON, S., HARMELIN, A., GOTTGENS, B. and IZRAELI, S. (2006) The SCL 3' enhancer responds to Hedgehog signaling during hemangioblast specification. Exp Hemato/34: 1643-1650.

HOOPER, J.E. (1994) Distinct pathways for autocrine and paracrine Wingless signalling in Drosophila embryos. Nature 372: 461-464.

HUBER, T.L., KOUSKOFF, V., FEHLING, H.J., PALIS, J. and KELLER, G. (2004) Haemangioblast commitment is initiated in the primitive streak of the mouse embryo. Nature 432: 625-630.

HUELSKEN, J., VOGEL, R., BRINKMANN, V., ERDMANN, B., BIRCHMEIER, C. and BIRCHMEIER, W. (2000) Requirement for beta-catenin in anterior-posterior axis formation in mice. J Cell Bio/148: 567-578.

HUPPERT, S.S., LE, A., SCHROETER, E.H., MUMM, J.S., SAXENA, M.T., MILNER, L.A. and KOPAN, R. (2000) Embryonic lethality in mice homozygous for a processing-deficient allele of Notch1. Nature 405: 966-970.

INGHAM, P.W. and MCMAHON, A.P. (2001) Hedgehog signaling in animal development: paradigms and principles. Genes Dev 15: 3059-3087.

ITOH, F., ITOH, S., GOUMANS, M.J., VALDIMARSDOTTIR, G., ISO, T., DOTTO, G.P., HAMAMORI, Y., KEDES, L., KATO, M. and TEN DIJKE PT, P. (2004) Synergy and antagonism between Notch and BMP receptor signaling pathways in endothelial cells. EMBO J23: 541-551.

JAFFREDO, T., GAUTIER, R., BRAJEUL, V. and DIETERLEN-LIEVRE, F. (2000) Tracing the progeny of the aortic hemangioblast in the avian embryo. Dev Biol 224: 204-214.
JI, J., VIJAYARAGAVAN, K., BOSSE, M., WEISEL, K. and BHATIA, M. (2008) OP9 Stroma augments survival of hematopoietic precursors and progenitors during hematopoietic differentiation from human embryonic stem cells. Stem Cells 26: 2485-2495.

JIA, J., AMANAI, K., WANG, G., TANG, J., WANG, B. and JIANG, J. (2002) Shaggy/ GSK3 antagonizes Hedgehog signalling by regulating Cubitus interruptus. Nature 416: 548-552.

KARANU, F.N., MURDOCH, B., GALLACHER, L., WU, D.M., KOREMOTO, M., SAKANO, S. and BHATIA, M. (2000) The notch ligand jagged-1 represents a novel growth factor of human hematopoietic stem cells. J Exp Med192: 13651372.

KARANU, F.N., MURDOCH, B., MIYABAYASHI, T., OHNO, M., KOREMOTO, M. GALLACHER, L., WU, D., ITOH, A., SAKANO, S. and BHATIA, M. (2001) Human homologues of Delta-1 and Delta-4 function as mitogenic regulators of primitive human hematopoietic cells. Blood97: 1960-1967.

KARANU, F.N., YUEFEI, L., GALLACHER, L., SAKANO, S. and BHATIA, M. (2003) Differential response of primitive human CD34- and CD34+ hematopoietic cells to the Notch ligand Jagged-1. Leukemia 17: 1366-1374

KELLY, O.G., PINSON, K.I. and SKARNES, W.C. (2004) The Wnt co-receptors Lrp5 and Lrp6 are essential for gastrulation in mice. Development 131: 28032815.

KENNEDY, M., D'SOUZA, S.L., LYNCH-KATTMAN, M., SCHWANTZ, S. and KELLER, G. (2007) Development of the hemangioblast defines the onset of hematopoiesis in human ES cell differentiation cultures. Blood109: 2679-2687.

KIMELMAN, D. and GRIFFIN, K.J. (2000) Vertebrate mesendoderm induction and patterning. Curr Opin Genet Dev 10: 350-356.

KIRSTETTER, P., ANDERSON, K., PORSE, B.T., JACOBSEN, S.E. and NERLOV, C. (2006) Activation of the canonical Wnt pathway leads to loss of hematopoietic stem cell repopulation and multilineage differentiation block. Nat Immuno/ 7: 1048-1056.

KLUMP, H., SCHIEDLMEIER, B. and BAUM, C. (2005) Control of self-renewal and differentiation of hematopoietic stem cells: HOXB4 on the threshold. Ann $N Y$ Acad Sci1044: 6-15.

$\mathrm{KOCH}$, U., WILSON, A., COBAS, M., KEMLER, R., MACDONALD, H.R. and RADTKE, F. (2008) Simultaneous loss of beta- and gamma-catenin does not perturb hematopoiesis or lymphopoiesis. Blood111: 160-164.

KOEBERNICK, K. and PIELER, T. (2002) Gli-type zinc finger proteins as bipotential transducers of Hedgehog signaling. Differentiation 70: 69-76.

KOHN, A.D. and MOON, R.T. (2005) Wnt and calcium signaling: beta-cateninindependent pathways. Cell Calcium 38: 439-446.

KREBS, L.T., SHUTTER, J.R., TANIGAKI, K., HONJO, T., STARK, K.L. and GRIDLEY, T. (2004) Haploinsufficient lethality and formation of arteriovenous malformations in Notch pathway mutants. Genes Dev 18: 2469-2473.

KUHL, M. (2002) Non-canonical Wnt signaling in Xenopus: regulation of axis formation and gastrulation. Semin Cell Dev Bio/13: 243-249.

KUMANO, K., CHIBA, S., KUNISATO, A., SATA, M., SAITO, T., NAKAGAMIYAMAGUCHI, E., YAMAGUCHI, T., MASUDA, S., SHIMIZU, K., TAKAHASHI, T., OGAWA, S., HAMADA, Y. and HIRAI, H. (2003) Notch1 but not Notch2 is essential for generating hematopoietic stem cells from endothelial cells. Immu nity 18: 699-711.

KYBA, M., PERLINGEIRO, R.C. and DALEY, G.Q. (2002) HoxB4 confers definitive lymphoid-myeloid engraftment potential on embryonic stem cell and yolk sac hematopoietic progenitors. Cel/109: 29-37.

LAKO, M., LINDSAY, S., LINCOLN, J., CAIRNS, P.M., ARMSTRONG, L. and HOLE, N. (2001) Characterisation of Wht gene expression during the differentiation of murine embryonic stem cells in vitro: role of Wnt3 in enhancing haematopoietic differentiation. Mech Dev 103: 49-59.

LEDRAN, M.H., KRASSOWSKA, A., ARMSTRONG, L., DIMMICK, I., RENSTROM, J., LANG, R., YUNG, S., SANTIBANEZ-COREF, M., DZIERZAK, E., STOJKOVIC, M., OOSTENDORP, R.A., FORRESTER, L. and LAKO, M. (2008) Efficient hematopoietic differentiation of human embryonic stem cells on stromal cells derived from hematopoietic niches. Cel/ Stem Cel/3: 85-98.

LEE, G.S., KIM, B.S., SHEIH, J.H. and MOORE, M. (2008) Forced expression of HoxB4 enhances hematopoietic differentiation by human embryonic stem cells. Mol Cells 25: 487-493.

LENGERKE, C., SCHMITT, S., BOWMAN, T.V., JANG, I.H., MAOUCHE-CHRETIEN 
L., MCKINNEY-FREEMAN, S., DAVIDSON, A.J., HAMMERSCHMIDT, M., RENTZSCH, F., GREEN, J.B., ZON, L.I. and DALEY, G.Q. (2008) BMP and Wnt specify hematopoietic fate by activation of the Cdx-Hox pathway. Cel/ Stem Cell 2: 72-82.

LITINGTUNG, Y., DAHN, R.D., LI, Y., FALLON, J.F. and CHIANG, C. (2002) Shh and $\mathrm{Gli} 3$ are dispensable for limb skeleton formation but regulate digit number and identity. Nature 418: 979-983.

LIU, P., WAKAMIYA, M., SHEA, M.J., ALBRECHT, U., BEHRINGER, R.R. and BRADLEY, A. (1999) Requirement for Wnt3 in vertebrate axis formation. Nat Genet 22: 361-365.

LOGAN, C.Y. and NUSSE, R. (2004) The Wnt signaling pathway in development and disease. Annu Rev Cel/ Dev Bio/20: 781-810.

LU, S.J., FENG, Q., CABALLERO, S., CHEN, Y., MOORE, M.A., GRANT, M.B. and LANZA, R. (2007b) Generation of functional hemangioblasts from human embryonic stem cells. Nat Methods 4: 501-509.

LU, S.J., FENG, Q., IVANOVA, Y., LUO, C., LI, T., LI, F., HONIG, G.R. and LANZA, R. (2007a) Recombinant HoxB4 fusion proteins enhance hematopoietic differentiation of human embryonic stem cells. Stem Cells Dev16: 547-559.

LU, X., BORCHERS, A.G., JOLICOEUR, C., RAYBURN, H., BAKER, J.C. and TESSIER-LAVIGNE, M. (2004) PTK7/CCK-4 is a novel regulator of planar cell polarity in vertebrates. Nature 430: 93-98.

LUM, L. and BEACHY, P.A. (2004) The Hedgehog response network: sensors, switches, and routers. Science 304: 1755-1759.

MAILLARD, I., KOCH, U., DUMORTIER, A., SHESTOVA, O., XU, L., SAI, H., PROSS, S.E., ASTER, J.C., BHANDOOLA, A., RADTKE, F. and PEAR, W.S. (2008) Canonical notch signaling is dispensable for the maintenance of adult hematopoietic stem cells. Cell Stem Cel/2: 356-366.

MALOOF, J.N., WHANGBO, J., HARRIS, J.M., JONGEWARD, G.D. and KENYON, C. (1999) A Wnt signaling pathway controls hox gene expression and neuroblast migration in C. elegans. Development 126: 37-49.

MANCINI, S.J., MANTEI, N., DUMORTIER, A., SUTER, U., MACDONALD, H.R. and RADTKE, F. (2005) Jagged1-dependent Notch signaling is dispensable for hematopoietic stem cell self-renewal and differentiation. Blood105:2340-2342.

MAYE, P., BECKER, S., KASAMEYER, E., BYRD, N. and GRABEL, L. (2000) Indian hedgehog signaling in extraembryonic endoderm and ectoderm differentiation in ES embryoid bodies. Mech Dev 94: 117-132.

MAZURIER, F., DOEDENS, M., GAN, O.I. and DICK, J.E. (2003) Rapid myeloerythroid repopulation after intrafemoral transplantation of NOD-SCID mice reveals a new class of human stem cells. Nat Med 9: 959-963.

MCKINNEY-FREEMAN, S.L. and DALEY, G.Q. (2007) Towards hematopoietic reconstitution from embryonic stem cells: a sanguine future. Curr Opin Hematol 14: 343-347.

MCMAHON, A.P., INGHAM, P.W. and TABIN, C.J. (2003) Developmental roles and clinical significance of hedgehog signaling. Curr Top Dev Bio/53: 1-114.

MENENDEZ, P., WANG, L. and BHATIA, M. (2005) Genetic manipulation of human embryonic stem cells: a system to study early human development and potential therapeutic applications. Curr Gene Ther 5: 375-385.

MERCHER, T., CORNEJO, M.G., SEARS, C., KINDLER, T., MOORE, S.A., MAILLARD, I., PEAR, W.S., ASTER, J.C. and GILLILAND, D.G. (2008) Notch signaling specifies megakaryocyte development from hematopoietic stem cells. Cell Stem Cel/3: 314-326.

MURDOCH, B., CHADWICK, K., MARTIN, M., SHOJAEI, F., SHAH, K.V., GALLACHER, L., MOON, R.T. and BHATIA, M. (2003) Wnt-5A augments repopulating capacity and primitive hematopoietic development of human blood stem cells in vivo. Proc Natl Acad Sci USA 100: 3422-3427.

MURDOCH, B., GALLACHER, L., CHADWICK, K., FELLOWS, F. and BHATIA, M. (2002) Human embryonic-derived hematopoietic repopulating cells require distinct factors to sustain in vivo repopulating function. Exp Hemato/30: 598605.

NAITO, A.T., SHIOJIMA, I., AKAZAWA, H., HIDAKA, K., MORISAKI, T., KIKUCHI, A. and KOMURO, I. (2006) Developmental stage-specific biphasic roles of Wnt/ beta-catenin signaling in cardiomyogenesis and hematopoiesis. Proc Nat/Acad SCi USA 103: 19812-19817.

NARAYAN, A.D., CHASE, J.L., LEWIS, R.L., TIAN, X., KAUFMAN, D.S., THOMSON, J.A. and ZANJANI, E.D. (2006) Human embryonic stem cell-derived hematopoietic cells are capable of engrafting primary as well as secondary fetal sheep recipients. Blood107: 2180-2183.

NEMIR, M., CROQUELOIS, A., PEDRAZZINI, T. and RADTKE, F. (2006) Induction of cardiogenesis in embryonic stem cells via downregulation of Notch1 signaling. Circ Res 98: 1471-1478.

NISHIKAWA, S.I., NISHIKAWA, S., HIRASHIMA, M., MATSUYOSHI, N. and KODAMA, H. (1998) Progressive lineage analysis by cell sorting and culture identifies FLK1+VE-cadherin + cells at a diverging point of endothelial and hemopoietic lineages. Development 125: 1747-1757.

NOBTA, M., TSUKAZAKI, T., SHIBATA, Y., XIN, C., MORIISHI, T., SAKANO, S. SHINDO, H. and YAMAGUCHI, A. (2005) Critical regulation of bone morphogenetic protein-induced osteoblastic differentiation by Delta1/Jagged1-activated Notch1 signaling. J Biol Chem 280: 15842-15848.

NOGGLE, S.A., WEILER, D. and CONDIE, B.G. (2006) Notch signaling is inactive but inducible in human embryonic stem cells. Stem Cells 24: 1646-1653.

NOSTRO, M.C., CHENG, X., KELLER, G.M. and GADUE, P. (2008) Wnt, activin, and $B M P$ signaling regulate distinct stages in the developmental pathway from embryonic stem cells to blood. Cel/ Stem Cel/2: 60-71.

NUSSE, R. (2008) Wnt signaling and stem cell control. Cell Res 18: 523-527.

OHISHI, K., VARNUM-FINNEY, B. and BERNSTEIN, I.D. (2002) Delta-1 enhances marrow and thymus repopulating ability of human CD34(+)CD38(-) cord blood cells. J Clin Invest 110: 1165-1174

ORKIN, S.H. and ZON, L.I. (2002) Hematopoiesis and stem cells: plasticity versus developmental heterogeneity. Nat Immuno/3: 323-328.

PALAPARTI, A., BARATZ, A. and STIFANI, S. (1997) The Groucho/transducin-like enhancer of split transcriptional repressors interact with the genetically defined amino-terminal silencing domain of histone H3. J Biol Chem272: 26604-26610.

PALIS, J. and YODER, M.C. (2001) Yolk-sac hematopoiesis: the first blood cells of mouse and man. Exp Hemato/29: 927-936.

PARK, I.H., ZHAO, R., WEST, J.A., YABUUCHI, A., HUO, H., INCE, T.A., LEROU, P.H., LENSCH, M.W. and DALEY, G.Q. (2008) Reprogramming of human somatic cells to pluripotency with defined factors. Nature 451: 141-146.

PEARSON, S., SROCZYNSKA, P., LACAUD, G. and KOUSKOFF, V. (2008) The stepwise specification of embryonic stem cells to hematopoietic fate is driven by sequential exposure to Bmp4, activin A, bFGF and VEGF. Development 135: 1525-1535.

PETROPOULOS, K., ARSENI, N., SCHESSL, C., STADLER, C.R., RAWAT, V.P., DESHPANDE, A.J., HEILMEIER, B., HIDDEMANN, W., QUINTANILLAMARTINEZ, L., BOHLANDER, S.K., FEURING-BUSKE, M. and BUSKE, C. (2008) A novel role for Lef-1, a central transcription mediator of Wnt signaling, in leukemogenesis. J Exp Med 205: 515-522.

QIAN, Z., CHEN, L., FERNALD, A.A., WILLIAMS, B.O. and LE BEAU, M.M. (2008) A critical role for Apc in hematopoietic stem and progenitor cell survival. J Exp Med205: 2163-2175.

RADTKE, F., WILSON, A. and MACDONALD, H.R. (2005) Notch signaling in hematopoiesis and lymphopoiesis: lessons from Drosophila. Bioessays 27 1117-1128.

RADTKE, F., WILSON, A., MANCINI, S.J. and MACDONALD, H.R. (2004) Notch regulation of lymphocyte development and function. Nat Immuno/5: 247-253.

RADTKE, F., WILSON, A., STARK, G., BAUER, M., VAN MEERWIJK, J., MACDONALD, H.R. and AGUET, M. (1999) Deficient T cell fate specification in mice with an induced inactivation of Notch1. Immunity 10: 547-558.

REUBINOFF, B.E., PERA, M.F., FONG, C.Y., TROUNSON, A. and BONGSO, A. (2000) Embryonic stem cell lines from human blastocysts: somatic differentiation in vitro. Nat Biotechno/18: 399-404.

REYA, T. and CLEVERS, H. (2005) Wnt signalling in stem cells and cancer. Nature 434: 843-850.

REYA, T., DUNCAN, A.W., AILLES, L., DOMEN, J., SCHERER, D.C., WILLERT, K., HINTZ, L., NUSSE, R. and WEISSMAN, I.L. (2003) A role for Wnt signalling in self-renewal of haematopoietic stem cells. Nature 423: 409-414.

ROBERT-MORENO, A., GUIU, J., RUIZ-HERGUIDO, C., LOPEZ, M.E., INGLESESTEVE, J., RIERA, L., TIPPING, A., ENVER, T., DZIERZAK, E., GRIDLEY, T., ESPINOSA, L. and BIGAS, A. (2008) Impaired embryonic haematopoiesis yet normal arterial development in the absence of the Notch ligand Jagged1. EMBO J27: 1886-1895.

RODAWAY, A. and PATIENT, R. (2001) Mesendoderm. an ancient germ layer? Cel/105: 169-172. 
SADLON, T.J., LEWIS, I.D. and D'ANDREA, R.J. (2004) BMP4: its role in development of the hematopoietic system and potential as a hematopoietic growth factor. Stem Cells 22: 457-474.

SAITO, T., CHIBA, S., ICHIKAWA, M., KUNISATO, A., ASAI, T., SHIMIZU, K., YAMAGUCHI, T., YAMAMOTO, G., SEO, S., KUMANO, K., NAKAGAMIYAMAGUCHI, E., HAMADA, Y., AIZAWA, S. and HIRAI, H. (2003) Notch2 is preferentially expressed in mature $B$ cells and indispensable for marginal zone B lineage development. Immunity 18: 675-685.

SCHELLER, M., HUELSKEN, J., ROSENBAUER, F., TAKETO, M.M., BIRCHMEIER, W., TENEN, D.G. and LEUTZ, A. (2006) Hematopoietic stem cell and multilineage defects generated by constitutive beta-catenin activation. Nat /mmuno/7: 10371047

SCHROEDER, T., MEIER-STIEGEN, F., SCHWANBECK, R., EILKEN, H., NISHIKAWA, S., HASLER, R., SCHREIBER, S., BORNKAMM, G.W. and JUST, U. (2006) Activated Notch1 alters differentiation of embryonic stem cells into mesodermal cell lineages at multiple stages of development. Mech Dev123: 570-579.

SENGUPTA, A., BANERJEE, D., CHANDRA, S., BANERJI, S.K., GHOSH, R., ROY, R. and BANERJEE, S. (2007) Deregulation and cross talk among Sonic hedgehog, Wnt, Hox and Notch signaling in chronic myeloid leukemia progression. Leukemia 21: 949-955.

SINHA, S. and CHEN, J.K. (2006) Purmorphamine activates the Hedgehog pathway by targeting Smoothened. Nat Chem Bio/2: 29-30.

STECCA, B. and RUIZI ALTABA, A. (2002) The therapeutic potential of modulators of the Hedgehog-Gli signaling pathway. JBio/1: 9.

STEWART, M.H., BOSSE, M., CHADWICK, K., MENENDEZ, P., BENDALL, S.C. and BHATIA, M. (2006) Clonal isolation of hESCs reveals heterogeneity within the pluripotent stem cell compartment. Nat Methods 3: 807-815.

SUMI, T., TSUNEYOSHI, N., NAKATSUJI, N. and SUEMORI, H. (2008) Defining early lineage specification of human embryonic stem cells by the orchestrated balance of canonical Wnt/beta-catenin, Activin/Nodal and BMP signaling. Development 135: 2969-2979.

TAIPALE, J., CHEN, J.K., COOPER, M.K., WANG, B., MANN, R.K., MILENKOVIC, L., SCOTT, M.P. and BEACHY, P.A. (2000) Effects of oncogenic mutations in Smoothened and Patched can be reversed by cyclopamine. Nature 406: 1005 1009

TAIPALE, J., COOPER, M.K., MAITI, T. and BEACHY, P.A. (2002) Patched acts catalytically to suppress the activity of Smoothened. Nature 418: 892-897.

TAKAHASHI, K. and YAMANAKA, S. (2006) Induction of pluripotent stem cells from mouse embryonic and adult fibroblast cultures by defined factors. Cel/126: 663676.

TAKIZAWA, T., OCHIAI, W., NAKASHIMA, K. and TAGA, T. (2003) Enhanced gene activation by Notch and BMP signaling cross-talk. Nucleic Acids Res 31: 57235731

TAVIAN, M., ROBIN, C., COULOMBEL, L. and PEAULT, B. (2001) The human embryo, but not its yolk sac, generates lympho-myeloid stem cells: mapping multipotent hematopoietic cell fate in intraembryonic mesoderm. Immunity 15: 487-495.

THOMSON, J.A., ITSKOVITZ-ELDOR, J., SHAPIRO, S.S., WAKNITZ, M.A., SWIERGIEL, J.J., MARSHALL, V.S. and JONES, J.M. (1998) Embryonic stem cell lines derived from human blastocysts. Science 282: 1145-1147.

TIAN, X. and KAUFMAN, D.S. (2008) Hematopoietic development of human embryonic stem cells in culture. Methods Mol Bio/430: 119-133.

TIAN, X., WOLL, P.S., MORRIS, J.K., LINEHAN, J.L. and KAUFMAN, D.S. (2006) Hematopoietic engraftment of human embryonic stem cell-derived cells is regulated by recipient innate immunity. Stem Cells 24: 1370-1380.

TROWBRIDGE, J.J., SCOTT, M.P. and BHATIA, M. (2006a) Hedgehog modulates cell cycle regulators in stem cells to control hematopoietic regeneration. Proc Natl Acad Sci USA 103: 14134-14139.

TROWBRIDGE, J.J., XENOCOSTAS, A., MOON, R.T. and BHATIA, M. (2006b) Glycogen synthase kinase-3 is an in vivo regulator of hematopoietic stem cell repopulation. Nat Med 12: 89-98.

UUSITALO, M., HEIKKILA, M. and VAINIO, S. (1999) Molecular genetic studies of Wnt signaling in the mouse. Exp Cel/ Res 253: 336-348.

VAN DEN BERG, D.J., SHARMA, A.K., BRUNO, E. and HOFFMAN, R. (1998) Role of members of the Wnt gene family in human hematopoiesis. Blood92: 3189
3202.

VARNUM-FINNEY, B., PURTON, L.E., YU, M., BRASHEM-STEIN, C., FLOWERS D., STAATS, S., MOORE, K.A., LE ROUX, I., MANN, R., GRAY, G., ARTAVANISTSAKONAS, S. and BERNSTEIN, I.D. (1998) The Notch ligand, Jagged-1, influences the development of primitive hematopoietic precursor cells. Blood 91: 4084-4091.

VIJAYARAGAVAN, K., SZABO, E., BOSSE, M., RAMOS-MEJIA, V., MOON, R.T. and BHATIA, M. (2009) Noncanonical Wnt signaling orchestrates early developmental events toward hematopoietic cell fate from human embryonic stem cells. Cell Stem Cel/ 4: 248-262.

VILLAVICENCIO, E.H., WALTERHOUSE, D.O. and IANNACCONE, P.M. (2000) The sonic hedgehog-patched-gli pathway in human development and disease. Am J Hum Genet 67: 1047-1054.

WANG, B., FALLON, J.F. and BEACHY, P.A. (2000) Hedgehog-regulated processing of Gli3 produces an anterior/posterior repressor gradient in the developing vertebrate limb. Ce//100: 423-434.

WANG, H., GILNER, J.B., BAUTCH, V.L., WANG, D.Z., WAINWRIGHT, B.J., KIRBY, S.L. and PATTERSON, C. (2007) Wnt2 coordinates the commitment of mesoderm to hematopoietic, endothelial, and cardiac lineages in embryoid bodies. J Biol Chem 282: 782-791.

WANG, L., LI, L., MENENDEZ, P., CERDAN, C. and BHATIA, M. (2005d) Human embryonic stem cells maintained in the absence of mouse embryonic fibroblasts or conditioned media are capable of hematopoietic development. Blood 105 : 4598-4603.

WANG, L., LI, L., SHOJAEI, F., LEVAC, K., CERDAN, C., MENENDEZ, P., MARTIN, T., ROULEAU, A. and BHATIA, M. (2004) Endothelial and hematopoietic cell fate of human embryonic stem cells originates from primitive endothelium with hemangioblastic properties. Immunity 21: 31-41.

WANG, L., MENENDEZ, P., CERDAN, C. and BHATIA, M. (2005c) Hematopoietic development from human embryonic stem cell lines. Exp Hemato/33: 987-996.

WANG, L., MENENDEZ, P., SHOJAEI, F., LI, L., MAZURIER, F., DICK, J.E., CERDAN, C., LEVAC, K. and BHATIA, M. (2005b) Generation of hematopoietic repopulating cells from human embryonic stem cells independent of ectopic HOXB4 expression. J Exp Med201: 1603-1614.

WANG, Y., YATES, F., NAVEIRAS, O., ERNST, P. and DALEY, G.Q. (2005a) Embryonic stem cell-derived hematopoietic stem cells. Proc Nat/ Acad Sci USA 102: 19081-19086.

WILLERT, K., BROWN, J.D., DANENBERG, E., DUNCAN, A.W., WEISSMAN, I.L., REYA, T., YATES, J.R.: 3RD and NUSSE, R. (2003) Wnt proteins are lipidmodified and can act as stem cell growth factors. Nature 423: 448-452.

WODARZ, A. and NUSSE, R. (1998) Mechanisms of Wnt signaling in development. Annu Rev Cell Dev Biol 14: 59-88.

WOLL, P.S., MORRIS, J.K., PAINSCHAB, M.S., MARCUS, R.K., KOHN, A.D., BIECHELE, T.L., MOON, R.T. and KAUFMAN, D.S. (2008) Wnt signaling promotes hematoendothelial cell development from human embryonic stem cells. Blood111: 122-131.

WU, C.H. and NUSSE, R. (2002) Ligand receptor interactions in the Wnt signaling pathway in Drosophila. J Biol Chem 277: 41762-41769.

XUE, Y., GAO, X., LINDSELL, C.E., NORTON, C.R., CHANG, B., HICKS, C. GENDRON-MAGUIRE, M., RAND, E.B., WEINMASTER, G. and GRIDLEY, T. (1999) Embryonic lethality and vascular defects in mice lacking the Notch ligand Jagged1. Hum Mol Genet 8: 723-730.

YU, J. and THOMSON, J.A. (2008) Pluripotent stem cell lines. Genes Dev22: $1987-$ 1997.

YU, J., VODYANIK, M.A., SMUGA-OTTO, K., ANTOSIEWICZ-BOURGET, J., FRANE, J.L., TIAN, S., NIE, J., JONSDOTTIR, G.A., RUOTTI, V., STEWART, R., SLUKVIN, II and THOMSON, J.A. (2007) Induced pluripotent stem cell lines derived from human somatic cells. Science 318: 1917-1920.

YU, X., ZOU, J., YE, Z., HAMMOND, H., CHEN, G., TOKUNAGA, A., MALI, P., LI, Y.M., CIVIN, C., GAIANO, N. and CHENG, L. (2008) Notch signaling activation in human embryonic stem cells is required for embryonic, but not trophoblastic lineage commitment. Cel/ Stem Cel/2: 461-471.

ZAMBIDIS, E.T., PEAULT, B., PARK, T.S., BUNZ, F. and CIVIN, C.I. (2005) Hematopoietic differentiation of human embryonic stem cells progresses through sequential hematoendothelial, primitive, and definitive stages resembling human yolk sac development. Blood 106: 860-870. 


\section{Further Related Reading, published previously in the Int. J. Dev. Biol.}

See our recent Special Issue Placenta edited by Joan S. Hunt and Kent L. Thornburg at: http://www.ijdb.ehu.es/web/contents.php?vol=54\&issue=2-3

Tracing the hemangioblast during embryogenesis: developmental relationships between endothelial and hematopoietic cells

Thierry Jaffredo, Karine Bollerot, Daisuke Sugiyama, Rodolphe Gautier and Cécile Drevon Int. J. Dev. Biol. (2005) 49: 269-277.

Embryonic development of the human hematopoietic system Manuela Tavian and Bruno Péault Int. J. Dev. Biol. (2005) 49: 243-250.

Embryonic stem cells and transgenic mice in the study of hematopoiesis $\mathrm{S} \mathrm{H}$ Orkin Int. J. Dev. Biol. (1998) 42: 927-934.

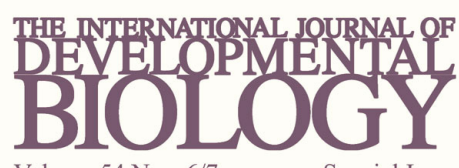

Volume 54 Nos. $6 / 7$

Special Issue
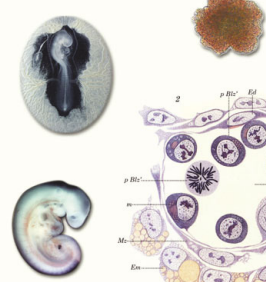

(2) 6 (4)
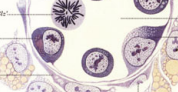

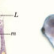

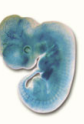

.
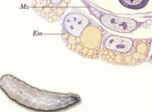

Developmental Hematopoiesis

Using EC and ES cell culture to study early development: recent observations on Indian hedgehog and Bmps

L Grabel, S Becker, L Lock, P Maye and T Zanders

Int. J. Dev. Biol. (1998) 42: 917-925.

Interactions between Wingless and Notch during the assignment of cell fates in Drosophila

A Martinez Arias

Int. J. Dev. Biol. (1998) 42: 325-333.
5 yr ISI Impact Factor $(2009)=3.253$

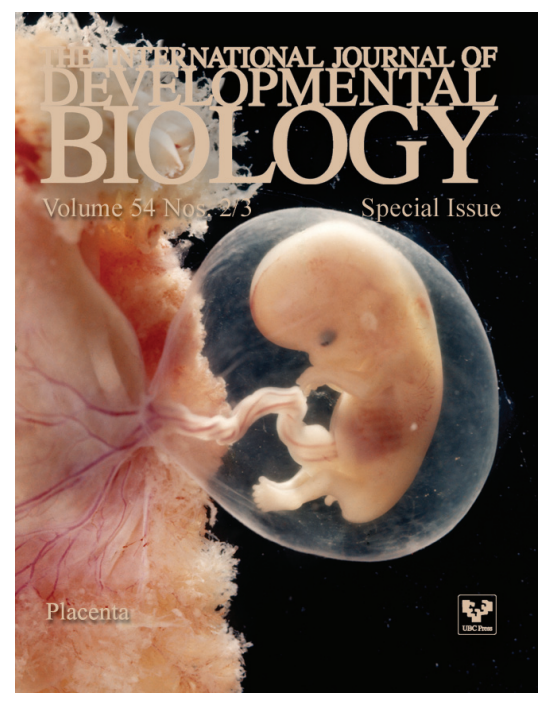

